\title{
Pojetí a rozvoj čtenářské pregramotnosti v předškolním období ${ }^{1}$
}

\author{
Jana Kropáčkováa, Radka Wildováa , Anna Kucharskáb \\ ${ }^{a}$ Univerzita Karlova v Praze, Pedagogická fakulta, Katedra primární pedagogiky

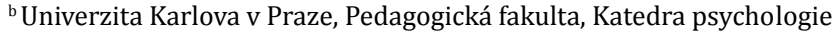

Redakci zasláno 27. 4. 2014 / upravená verze obdržena 13. 7.2014 /

k uveřejnění přijato 15. 7. 2014

\begin{abstract}
Abstrakt: Příspěvek se zaměřuje na problematiku čtenářské pregramotnosti, která je z pohledu celoživotního vzdělávání nesmírně významnou oblastí, nebot' v období předškolního věku se kladou základy nejen čtenářské, ale i řady dalších gramotností a současně se rozvíjí osobnost dítěte, jeho motivace pro vlastní poznávání. Cílem studie je charakterizovat pojetí čtenářské pregramotnosti v českém předškolním vzdělávání, analyzovat vývoj související terminologie a sumarizovat závěry výzkumných šetření zaměřujících se na pojetí, podporu a rozvoj čtenářské pregramotnosti v domácím prostředí. Autorky se zaměří v prvé části na vývoj terminologie, konkrétně používání pojmů v českém předškolním vzdělávání, dále na precizaci pojmů z vývojového hlediska a v kontextu současného českého předškolního kurikula. Druhou část věnují prezentaci výsledků výzkumných šetření v oblasti čtenářské pregramotnosti a třetí část zařazení této problematiky v pregraduální přípravě učitelek mateřských škol na PedF UK v Praze a dalším možnostem podpory rozvoje v předškolním období, které je považováno i v zahraniční odborné literatuře za jedno z klíčových období v rozvoji čtenářské gramotnosti. Díky tomuto postupu autorky v závěrečné části objasňují preferenci používání pojmu čtenářské pregramotnosti a docházejí ke zjištění, že k pojetí a rozvoji čtenářské pregramotnosti je třeba přistupovat komplexně, jak ve výzkumu, tak ve vlastní přípravě učitelů a samotném předškolním vzdělávání.
\end{abstract}

Klíčová slova: předškolní vzdělávání, mateřská škola, dítě předškolního věku, rodinná výchova, čtenářské dovednosti, čtenářská gramotnost, předčtenářská výchova, čtenářská pregramotnost

Přehledová studie je věnována problematice čtenářské pregramotnosti. Je všeobecně známo, že klíčovou dovedností čtenářské gramotnosti, kterou si dítě osvojuje v prvním roce školní docházky, je čtení. Jelikož v současné době představuje osvojení dobré čtenářské dovednosti „,klíč, kterým se dítěti

1 Studie byla zpracována v rámci Programu rozvoje vědních oblastí na Univerzitě Karlově P15 Škola a učitelská profese v kontextu nároků na vzdělávání.

DOI: $10.5817 /$ PedOr2014-4-488 
otevírají dveře ke vzdělání", dostává se do centra české vzdělávací politiky i zájmu odborné i široké veřejnosti téma podpory i již v předškolním období. Např. Mertin (2003, s. 121) zdůrazňuje, že pokud si dítě neosvojí čtenářské dovednosti na počátku školní docházky, tak je v současném běžném životě nedokáže ničím nahradit, má špatné výsledky ve škole a je funkčně negramotné. Tyto děti mají v pozdějším věku ztížený až omezený přístup ke vzdělání (srov. Rabušicová, 2002; Gavora \& Zápotočná, 2003; Doležalová, 2009; Najvarová, 2010; Helus, 2012), dosahují nižšího stupně vzdělání, mají problémy v pracovním či společenském uplatnění a častěji se u nich může objevit společensky nežádoucí chování (drogová závislost, kriminalita atd.). Zde spočívá vedle rozvoje osobnosti dítěte jeden z důležitých aspektů předškolního vzdělávání, které může explicitně rozvíjet a podporovat dovednosti, které budou při rozvoji gramotnostních dovedností ve školním věku potřebné, př́padně i upozornit na př́padné vývojové problémy a dát podnět pro jejich včasné řešení (podrobněji viz Švancarová \& Kucharská, 2012; Jagerčíková \& Kucharská, 2012; Wildová, 2012; Vykoukalová \& Wildová, 2013).

Význam předškolního vzdělávání je v současné době nejenom v zahraničí, ale i v České republice spatřován především v položení základů pro celoživotní učení a snížení nerovnosti ve výsledcích vzdělávání, což dokládají i výsledky $\mathrm{v}$ testech PISA. V těchto mezinárodních srovnáních bylo zjištěno, že žáci, kteří navštěvovali předškolní vzdělávání, dosahují lepších výsledků v testech PISA ${ }^{2}$ a častěji vstupují do terciárního vzdělávání (srov. OECD, 2013).

$\mathrm{V}$ předškolním období působí na dítě společně s mateřskou školou také jeho rodina, nebot' řady cílů předškolního vzdělávání dítě dosahuje právě prostřednictvím spolupráce mezi nimi. Česká mateřská škola rozvíjí a kultivuje předškolní dítě v celé šíři jeho osobnosti a může mu pomoci vyrovnat určité nedostatky rodinného prostředí. Právě přirozené sociální prostředí vrstevníků činí mateřskou školu v současné době nenahraditelnou (srov. Opravilová \& Gebhartová, 2003), protože dítě je zde rozvíjeno, podporováno a motivováno s ohledem na jeho individuální potřeby i schopnosti, což mu usnadňuje jeho další životní dráhu a vytváří optimální předpoklady pro další vzdělávací cestu.

Předškolnímu období je $\mathrm{v}$ posledních letech přikládán velký význam i z hlediska rozvoje čtenářské gramotnosti. $V$ tomto kontextu je právě předškolní

2 Ve Zpravodaji PISA in Focus č. 40 (2014) bylo prezentováno, že děti, které se neúčastnily předškolního vzdělávání, mají v průměru o 51 bodů horší výsledky v testech v 15 letech. 
období vnímáno jako jeden ze základních pilírư rozvoje čtenářské gramotnosti, obecněji i celého komplexu gramotnosti. V České republice není smyslem tohoto období systematicky a cíleně učit dítě číst a psát, ale vytvářet $\mathrm{u}$ dítěte pozitivní vztah $\mathrm{k}$ psané řeči, otevř́ít a stimulovat u něj schopnosti a dovednosti, které mu umožní se ve čtení a psaní v budoucnu optimálně rozvíjet. Důraz je kladen na rozvoj pozitivní motivace pro čtení a psaní. Smyslem je nenásilně a formou hry podporovat rozvoj oblastí, které pro budoucí výuku čtení a psaní budou potřebné a mohou tak dítěti osvojování těchto dovedností významně usnadnit.

Těžiště přehledové studie tvoří analýza dostupných výzkumných šetření $\mathrm{k}$ pojetí čtenářské pregramotnosti $\mathrm{v}$ českém prostředí v kontextu kurikulární reformy, s ohledem na závěry prezentované ve Výroční zprávě České školní inspekce... (dále ČŠI; 2013) a poukazovanou absenci podpory rozvoje čtenářské pregramotnosti $\mathrm{v}$ Rámcovém vzdělávacím programu pro předškolní vzdělávání (dále RVP PV, 2004), kde naopak je používán termín kompetence. V souvislosti s komplexní podporou rozvoje pregramotnosti jsme se současně zaměřili na téma čtenářské pregramotnosti v přípravě učitelů na Pedagogické fakultě UK v Praze.

\section{Objasnění vývoje základní terminologie}

\subsection{Pojetí čtenářské gramotnosti}

Čtenářská gramotnost je jedním z druhů obecné gramotnosti, který je považován za základní ukazatel vzdělanosti národa, ale i za faktor hospodářského rozvoje země (srov. Doležalová, 2009; Rabušicová, 2002; Straková et al., 2002; UNESCO, 1958; Wildová, 2012 atd.). Definování pojmu gramotnost (literacy) není jednoduché, nebot' se jedná o komplikovaný, komplexní a zároveň proměnlivý jev s aspektem individuální variability (srov. Doležalová, 2009; Rabušicová, 2002). Jednotliví autoři mohou přitom akcentovat jiné aspekty tohoto pojmu.

V nejobecnější podobě můžeme gramotnost chápat jako „prostředek akulturace jedince“ (Pupala \& Zápotočná, 2001, s. 264). Jiná pojetí jsou ta, která akcentují dispoziční složku. $Z$ výše uvedeného vyplývá, že se jedná o připravenost jedince $\mathrm{k}$ činnostem, pomocí kterých se stává členem společnosti, kdy na jedné straně využívá jejích výdobytků, a na druhé straně splňuje nároky společností kladené, jejichž rozvinutí je nutné do úspěšného zapojení do společnosti. 
Např. podle Průchy, Walterové a Mareše (2003, s. 70) je gramotností chápána „dovednost číst a psát získaná obvykle v počátečních ročnících školní docházky“. Podobné pojetí je i u Hartla a Hartlové, kteří pod gramotností vidí „blíže nespecifikovanou schopnost číst a psát" (Hartl \& Hartlová, 2000, s. 182). Můžeme k nim počítat i definici gramotnosti z Pedagogické encyklopedie, podle které gramotnost „znamená schopnost ovládat různé druhy komunikace a početních úkonů za účelem využívání textových informací v rozmanitých životních situacích“ (Doležalová, 2009, s. 223). Považujeme ji za zastřešující vzhledem k současnému pojetí směřujícímu k funkční gramotnosti.

Čtenářská gramotnost zahrnuje „rozsáhlý komplex dovedností a kompetencí, ovlivňující gramotnosti další" (Wildová, 2012, s. 10). Odráží v obecné rovině stupeň učení, ve kterém lze rozlišit dvě základní úrovně gramotnosti, lišící se mírou aktivity jedince, které však mohou mít i svou vývojovou dimenzi. První úrovně čtenářské gramotnosti dosáhne jedinec, který je pouhým tzv. konzumentem. Tento „pasivní čtenár̆“ si určitý text poslechne, přečte, zapamatuje si ho, ale nezapojuje kognitivní procesy vyšší úrovně. Ve druhé úrovni je jedinec již aktivním čtenářem, který dokáže zpracovat a dekódovat textové informace na úrovni vyšších kognitivních operací (hodnocení, vyvození atd.). První úroveň bývá označována jako bázová gramotnost, opírající se o gramotnostní dovednosti, a druhá jako gramotnostní kompetence, zahrnující komplexnější předpoklady (Gavora et al., 2002). Zatímco první úroveň je běžná v rámci etapy počátečního čtení, ke druhé úrovni žáci dospívají během etapy rozvíjející se čtenářské gramotnosti.

Zajímavou kategorizaci prezentuje Helus (2012), který chápe čtenářství jako naplnění smyslu výuky čtení a vymezuje čtyři klíčové události na cestě ke čtenářské gramotnosti: fáze vytváření bázových predispozic pro čtení (jejich předškolní rozvíjení), fáze soustavné školní výuky čtení a psaní, fáze uvádění do čtenářství (zvládnutá gramotnost se stává funkční gramotností) a fáze aktivního čtenářství.

Na základě analýzy různých vymezení a definování pojmu čtenářská gramotnost lze konstatovat, že v současné době se výrazně obsah pojmu čtenářská gramotnost rozšiřuje, a to především s důrazem na její pragmatickou složku. Stručně připomeňme, že termín čtenářská gramotnost se do české odborné terminologie dostává ze zahraničí v 90 . letech minulého století v souvislosti s mezinárodními výzkumy čtenářské gramotnosti (PISA, PIRLS atd.). Vzhledem $\mathrm{k}$ tomu, že problematika čtenářské gramotnosti je problematikou rozsáhlou a do jisté míry i problematikou komplexní, lze na ni z hlediska vě- 
deckých teorií nahlížet z různých hledisek, např. z hlediska lingvistického, sociolingvistického, sociokulturního, ontogenetického atd. Pojetí čtenářské gramotnosti se formovalo a formuje v souvislosti s měnícím se vývojem podmínek a potřeb společnosti, což ovlivňuje nejen definování a obsah pojmu čtenářská gramotnost, ale např. v oblasti vzdělávání také metody a způsob jejího rozvoje, stanovené cíle a předpokládané dosažené kompetence jedince.

V mezinárodním kontextu jsou respektovány definice prezentované v rámci výzkumů TIMSS, PISA a PIRLS „schopnost porozumět psanému textu, přemýšlet o něm a používat jej $\mathrm{k}$ dosažení vlastních cílů, k rozvoji vlastních vědomostí a potenciálu a k aktivní účasti ve společnosti“" (Straková et al., 2002, s. 111). Definování čtenářské gramotnosti vychází z anglosaského pojetí koncepce gramotnosti a je chápáno jako základní kulturní nástroj člověka nezbytný pro jeho život ve společnosti.

Čtenářská gramotnost je také významnou součástí rozvoje dalších gramotností (přírodovědné, matematické, počítačové, mediální atd.). Z tohoto pojetí bychom mohli také vycházet při operacionalizaci pojmu pregramotnost a analogicky bychom $\mathrm{k}$ němu mohli přiřadit příslušná adjektiva (čtenářská, matematická, přírodovědná aj.).

V souvislosti $s$ možným členěním čtenářské gramotnosti je vhodné uvést i aktuální přístup, který byl zveřejněn v metodické příručce Čtenářská gramotnost ve výuce (2011), kde český tým odborníků uvádí šest rovin čtenářské gramotnosti: vztah ke čtení, doslovné porozumění, vysuzování, metakognice, sdílení a aplikace. Kategorizace uvedených rovin čtenářské gramotnosti je využitelná nejen výzkumně, ale především didakticky, nebot' vychází z klasifikace čtenářských strategií.

Čtenářská gramotnost je tedy obecně vnímána jako komplex schopností a dovedností využívat psanou řeč pro komunikaci, zábavu, vzdělávání atd. Její podstatou není pouze schopnost psanou řeč „technicky“ správně přečíst, ale také jí porozumět, dále s ní pracovat, kriticky zhodnotit a využít potřebné informace (tzv. funkční využitelnost čtení a psaní) a zároveň rozvíjet pozitivní a aktivní vztah k psané řeči (srov. Wildová, 2012). Právě tyto čtenářské strategie podporující aktivní a autonomní práci s texty usnadňují porozumění textu a jsou základem čtenářské gramotnosti. V českých základních školách jsou rozvíjeny především čtenářské dovednosti. Podstatně méně jsou žáci systematicky vedeni k rozvoji a používání různých čtenářských strategií (srov. Najvarová, 2010). 
Za čtenářskou pregramotnost považujeme

soubor postupně se rozvíjejících předpokladů pro čtení a psaní u dětí v široké době před nástupem do školy. Jedná se o komplex schopností, dovedností, postojů a hodnot potřebných pro zahájení a úspěšné rozvíjení čtenářské gramotnosti i jejímu užívání v různých individuálních a sociálních kontextech. (Kucharská, 2014, s. 40)

Shrneme-li terminologii spojenou s pojmem čtenářská pregramotnost a čtenářská gramotnost, docházíme $\mathrm{k}$ následující terminologické a obsahové strukturaci. Gramotnost v preprimárním vzdělávání (tzv. pregramotnost) je charakterizována rozvojem předgramotnostních dovedností v předškolním věku. Dalším stupněm je čtenářská (tzv. základní) gramotnost, která označuje rozvoj gramotnostních dovedností v období povinné školní docházky. $\mathrm{V}$ tomto časově dlouhém úseku čtenářské gramotnosti je podstatné z didaktického hlediska rozlišit počáteční čtenářskou gramotnost, která má své specifické cíle, metody atd. Posledním stupněm v takto ontogeneticky pojaté hierarchii je funkční gramotnost, zahrnující rozvoj gramotnostních dovedností dospělých jedinců.

Na základě analýzy uvedených zdrojů a s ohledem na ontogenetický vývoj jedince se autorky domnívají, že je vhodnější používání termínu čtenářská pregramotnost než předčtenářská gramotnost, nebo dokonce čtenářská gramotnost $\mathrm{v}$ předškolním věku. Jedná se o významné období, kdy se kladou a rozvíjí počáteční zárodky budoucí čtenářské gramotnosti, tedy pregramotnosti. Použití předpony pre- je terminologicky v souladu i s označením vzdělávacího stupně ISCED 0 , který se v českém prostředí ujal pod označením preprimární stupeň vzdělávání.

\subsection{Význam období pregramotnosti}

Gramotnost a pregramotnost může být však pojímána ve vztahu k ontogenetickému vývoji jedince. Období pregramotnosti je považováno i v zahraniční odborné literatuře za jedno z klíčových období v rozvoji čtenářské gramotnosti. Rozvoj pregramotnosti (gramotnosti v předškolním věku) začíná narozením jedince a pokračuje až do vstupu dítěte do školy. Cílem tohoto období je vytvářet $u$ dítěte pozitivní vztah $k$ psané řeči a otevřít a stimulovat $u$ něj schopnosti a dovednosti, které mu umožní se ve čtení a psaní v budoucnu optimálně rozvíjet. Důraz je především kladen na komunikaci, rozvoj pozitivní motivace pro čtení a psaní, nebot' dítě se v předškolním období cíleně neučí 
číst a psát. Smyslem je dávat mu podněty, které u něj zájem o čtení vzbudí a ukážou mu „využitelnost" těchto dovedností. Mateřská škola by měla v úzké spolupráci s rodinou nenásilně a formou hry podporovat rozvoj oblastí, které s výukou čtení a psaní zcela přímo souvisí (řeč a jazykové schopnosti a dovednosti, percepčně motorické funkce, kognitivní funkce) a mohou tak dítěti osvojování těchto dovedností v budoucnu výrazně usnadnit. Charakteristickým a velmi významným rysem období pregramotnosti je spontánnost dítěte v objevování psané řeči a hledání způsobů jejího „uchopení“.

K významu přečtenářské gramotnosti se vyslovuje i Tematická zpráva ČŠI, podle které období pregramotnosti

vytváŕí prostor pro získání prožitku ze čtení, ale také základů čtenářských dovedností (např. vizualizace, předvídání, hledání souvislostí). Promyšlený a vědomý př́stup $\mathrm{k}$ utváření těchto dovedností $\mathrm{v}$ raném věku pak umožňuje jejich aplikaci do běžného života dítěte, čímž se rozvoj předčtenářských dovedností stává nenásilným a přirozeným procesem. (Podpora rozvoje..., 2011, s. 5)

Z výše uvedeného vyplývá, že předčtenářské dovednosti jsou rozvíjeny a podporovány především před zahájením povinné školní docházky. Se vstupem dítěte do 1 . tř́dy je postupně realizovaná systematická výuka čtení v součinnosti s rozvojem psaní a podporou rozvoje počáteční čtenářské gramotnosti. Kucharská a Veverková (2012) uvádějí, že v počáteční etapě sehrávají významnou úlohu: individuální schopnosti dítěte v předpokladech pro psaní a čtení, osobnostní charakteristiky a zkušenosti dítěte podobně jako samotný učitel a využívání vhodných metodických a didaktických postupů pro rozvoj čtení a psaní.

Počátky pregramotnosti se utvářejí již u nejmladších dětí, ve chvíli, kdy se seznamují se slovy, prohlíží si obrázky, listují v prvních dětských knihách „leporelech“, později, kdy jim rodiče předčítají knihy či si navzájem vyprávějí své vlastní příběhy. Významnou součástí tzv. předčtenářské výchovy v předškolním období je rozvoj vnitřní motivace pro čtenía s tím souvisejícího pozitivního vztahu ke čtení. Specifické projevy tzv. předčtenářského chování dítěte lze vhodně využívat i při pedagogické diagnostice, konkrétně čtenářská pregramotnost může velmi pozitivně ovlivňovat školní připravenost dítěte při vstupu do školy. Obsahově i didakticky specifickou a velmi významnou oblastí vzdělávání v předškolním věku je rozvoj řeči a jazykových schopností a dovedností, s nimiž rozvoj čtenářské pregramotnosti úzce souvisí. 


\section{3 Čtenářská pregramotnost v českém předškolním kurikulu}

Při vymezování pojmu gramotnost a pregramostnost bychom neměli opomenout, že mohou mít také vyzývací charakter, kdy jsou specifikovány požadavky na jejich rozvoj v jednotlivých úrovních vzdělávání (ISCED) a kdy se tedy stávají jedním z obsahů či témat kurikula. Při analýze RVP PV (2004) bylo zjištěno, že v tomto kurikulárním dokumentu, dle kterého musí všechny mateřské školy od 1. záŕí 2007 tvořit své školní vzdělávací programy, není explicitně zpracována oblast rozvoje dovedností, které předcházejí čtení. $\mathrm{V}$ textu ani ve Slovníčku (RVP PV, 2004) použitých výrazů nenalezneme objasnění termínu předčtenářská gramotnost či čtenářská pregramotnost. Naopak zde ale nalezneme objasnění pojmu klíčové kompetence a klíčové kompetence v předškolním vzdělávání (RVP PV, 2004, s. 46) a taktéž výčet osmi komunikativních kompetencí, kterých by dítě mělo dosáhnout na konci předškolního vzdělávání (RVP PV, 2004, s. 13). Při podrobné analýze komunikativních kompetencí a jednotlivých vzdělávacích oblastí však zjištujujeme, že se s rozvojem předčtenářských dovedností implicitně počítá ${ }^{3}$.

Některé dílčí vzdělávací cíle směřující k podpoře a rozvoji čtenářské pregramotnosti lze dohledat také ve vzdělávací oblasti Dítě a společnost (RVP PV, 2004, s. 26), kdy předškolní pedagog seznamuje dítě se společenstvím ostatních lidí, kulturou a umožňuje mu aktivně se vyjadřovat a projevovat. Můžeme tedy obecně konstatovat, že v RVP PV (2004) není sice precizována podpora rozvoje pregramotností (čtenářské, matematické, prŕrodovědné, polytechnické, mediální atd.), avšak při detailní analýze vzdělávacích oblastí (především 5.2, 5.3, 5.4) nalezneme nejenom dílčí cíle směřující k podpoře rozvoje čtenářské pregramotnosti, ale i konkrétní vzdělávací nabídku, kterou by předškolní pedagog měl dítěti „nabízet“ a kreativně a nenásilně zařazovat do předškolního vzdělávání ${ }^{4}$.

\footnotetext{
Ve vzdělávací oblasti Dítě a jeho psychika v podoblasti Jazyk a řeč jsou formulovány dílčí vzdělávací cíle směřující $\mathrm{k}$ podpoře a rozvoji čtenářské pregramotnosti: rozvoj řečových schopností a jazykových dovedností receptivních (vnímání, naslouchání, porozumění) i produktivních (výslovnosti, vytváření pojmů, mluvního projevu, vyjadřování); rozvoj komunikativních dovedností (verbálních i neverbálních) a kultivovaného projevu; osvojení si některých poznatků a dovedností, které předcházejí čtení i psaní, rozvoj zájmu o psanou podobu jazyka i další formy sdělení verbální i neverbální (výtvarné, hudební, pohybové, dramatické). (RVP PV, 2004, s. 18)

4 Jedná se o: společné diskuze, rozhovory, individuální konverzace; komentování zážitků a aktivit, vyřizování výdajů a zpráv; vyprávění toho, co dítě slyšelo; prohlížení a „čtení knížek; vysvětlování, objasňování, práce s knihou; aktivní naslouchání druhému; receptivní slovesné, literární či dramatické činnosti (poslech pohádek, prŕiběhů); tvưrčí činností slovesné, literární, dramatické podněcující tvořivost a vyjadřování atd.
} 
Pojem čtenářská pregramotnost se v RVP PV neobjevuje, a tak jednotlivé její složky jsou většinou do předškolního vzdělávání zařazovány nekoncepčně, což je jeden z možných důvodů, proč rozvoj čtenářské pregramotnosti není řešen jako jeden $\mathrm{z}$ dlouhodobých vzdělávacích cílů ve školních vzdělávacích programech. RVP PV však (2004) lze hodnotit jako nadčasové a velmi kvalitně zpracované předškolní kurikulum, nebot' již před 10 lety jeho tvůrci vzdělávací obsah neuspořádali do předmětů jako na základní škole ani do tzv. výchovných složek, tak jako tomu bylo v předchozím Programu výchovné práce $v$ jeslích a mateřských školách (1984), ale do integrovaných vzdělávacích oblastí směřujících k podpoře rozvoje osobnosti dítěte. Bohužel při implementaci nového předškolního kurikula, vycházejícího $\mathrm{z}$ osobnostně orientovaného pojetí výchovy, chyběly předškolním pedagogům metodiky, na jejichž absenci poukazují i v současnosti (Kropáčková, 2013). Ve většině mateřských škol ještě stále učitelky využívají starší metodiky, které doplňovaly již zmiňovaný Program výchovné práce v jeslích a mateřských školách (1984), avšak konkrétně v oblasti metodiky literární výchovy (Kádnerová, 1982; Strnadová et al., 1989) se většinou zaměřovaly pouze na výchovu k literatuře, výchovu literaturou a v roce 1989 i na dramatickou výchovu. Nelze se tedy divit zjištění ČSI (Výroční zpráva..., 2013), že předškolní pedagogové nedostatečně stimulují děti k samostatnému vyhledávání informací, nebot' většina z nich se $s$ problematikou rozvoje čtenářské pregramotnosti nesetkala $v$ rámci pregraduálního studia, ale ani dalšího vzdělávání učitelů. V RVP PV (2004) jsou sice vymezeny klíčové kompetence dítěte ukončující předškolní vzdělávání, které směřují k rozvoji pregramotnosti, avšak z hlediska jejich obsahu zde nejsou konkretizovány. Učitelky mateřských škol se zaměřují na rozvoj řečových schopností, jazykových receptivních dovedností a dovedností předcházejících čtení a psaní (prohlížení knih, vyhledávání v encyklopediích atd.) tak, jak je doporučováno ve starších metodikách. K rozvoji čtenářské pregramotnosti je však potřeba přistupovat komplexněji a neopomíjet i další roviny pregramotnosti: vztah ke čtenému a psanému textu, porozumění čteného či vyprávěného textu, hledání souvislostí a hodnocení čteného a vyprávěného textu, domýšlení nedokončeného čteného či vyprávěného textu a zaujmutí postoje $\mathrm{k}$ předčítanému textu a vyvození konkrétního poučení pro život. Tento přístup koresponduje s dosavadní informovaností učitelek mateřských škol o rozvoji čtenářských dovedností a současném pojetí osobnostně orientované výchovy, která se zaměřuje na rozvoj celé osobnosti dítěte. Učitelky mateřských škol proto pozitivně uvítaly zpracování Konkretizovaných očeká- 
vaných výstupů (2012), nebot’ stále postrádají metodiky, avšak odborná pedagogická veřejnost upozorňovala na případné nebezpečí, v př́ípadě, že by se materiál stal normou, dle které by se děti testovaly (srov. Průběžný souhrn diskuze..., 2013; Kropáčková, 2013).

V kontextu kurikulárních dokumentů evropských zemí (viz Eurydice, 2012) je společným trendem $\mathrm{v}$ rozvoji čtenářské gramotnosti koncept preferující tzv. období pregramotnosti, kdy se děti systematicky neučí číst. Naopak toto období je maximálně využito $\mathrm{k}$ podpoře předčtenářských dovedností, $\mathrm{k}$ tzv. př́pravě na čtení, k rozvoji jazykových schopností a dovedností, korekci logopedických vad a také k rozvoji poznávacích a psychických procesů, které se čtením velmi úzce souvisejí (zrakové, sluchové vnímaní, motorika, pozornost, představivost, pamět' atd.).

Současné předškolní vzdělávání v ČR je založeno na holistickém př́ístupu $\mathrm{k}$ dítěti s důrazem na vlastní aktivitu dítěte a důležitost hry $\mathrm{v}$ jeho vývoji. V mezinárodním porovnání kurikulárních dokumentů pro ISCED 0 byl český RVP PV (2004) vyhodnocen jako celkově dobře strukturovaný dokument (srov. Syslová, Borkovcová, \& Průcha, 2014) s vyváženým obsahem, pokrývající kognitivní a socio-emoční předmětové oblasti, s drobnými nedostatky, na které poukázala i ČŠI (srov. Podpora rozvoje..., 2013). Byly zjištěny rozdíly $\mathrm{v}$ kvalitě předškolního vzdělávání přímo související s rozvojem funkčních gramotností. Tuto rozporuplnost lze vysvětlit problémy v samotné implementaci kurikula, nedostatečnými a nekoordinovanými zdroji informací pro předškolní pedagogy, ale i vysokým počtem dětí ve třídě mateřské školy, což je ve shodě s identifikovanými riziky kvality, která byla identifikována OECD (2012).

\section{Výzkumná šetř̌ení zaměřující se na pojetí, podporu a rozvoj čtenářské pregramotnosti v domácím prostředí}

\subsection{Odlišnosti v používání základní terminologie}

Nejednotnost $\mathrm{v}$ odborné terminologii lze doložit aktuálními výzkumy v oblasti čtenářské pregramotnosti. Franke a Mikulajová (2012) zkoumaly vývoj klíčových dovedností pro rozvoj čtení u slovensky hovořících dětí s různými profily jazykových schopností a ve své studii používaly termín předgramotnostní dovednosti a Homolová (2012) ve studii věnované diagnostice čtenář- 
ských prekonceptů používá termín čtenářské prekompetence. Mertin (2003) využívá termínu předčtenářské dovednosti.

Předškolní pedagogové sice zařazují aktivity na podporu rozvoje čtenářské pregramotnosti, ale mají problém s rozlišením a chápáním pojmů klíčová kompetence a pregramotnost. Toto tvrzení autorky opírají o výzkumné šetření (srov. Kropáčková, 2013) na základě analýzy 81 seminárních prací studentek kombinovaného studia bakalářského oboru Učitelství pro mateřské školy a navazujícího magisterského oboru Pedagogika předškolního věku, které zjištovalo, jak je chápán a naplňován Rámcový vzdělávací program pro předškolní vzdělávání v praxi, tedy pregramotnost z kurikulárního pohledu. Je třeba zdůraznit, že se 80 respondentek ztotožňovalo s osobnostně orientovanou koncepcí a nepožadovalo změnu RVP PV, avšak jedním z velmi silně zastoupených návrhů k doplnění RVP PV bylo vytvoření metodik na podporu a rozvoj pregramotností společně $\mathrm{s}$ objasněním aktuálně používané terminologie, např. formou rozšíření tzv. „komentovaného“ Slovníčku použitých výrazů (RVP PV, 2004, s. 46-48).

\subsection{Zjištění České školní inspekce ve vztahu ke čtenářské pregramotnosti}

Ve Výroční zprávě České školní inspekce (2013) je uvedeno, že na budoucí úspěšnost $\mathrm{v}$ dalším vzdělávání mají výrazný vliv dovednosti, které předcházejí čtení a psaní. ČŠI se proto při hodnocení naplňování požadovaných výstupů dle vzdělávacích oblastí zaměřila i na ty oblasti předškolního vzdělávání, které přímo souvisejí s rozvojem funkčních gramotností, tedy i předčtenářskou gramotností ve smyslu rozvoje dispoziční složky pregramotnosti. Jedná se konkrétně o dovednost práce s textem, práce se zdroji a vyhledávání informací. Dle závěrů ČSI vyplynulo, že děti projevovaly přirozený zájem o knihy i encyklopedie a měly k nim neomezený přístup, ale předškolními pedagogy nebyly dostatečně stimulovány k samostatnému vyhledávání informací. Samozřejmě lze diskutovat, zda právě tento moment je z vývojového hlediska tou zásadní proměnnou, která předurčuje budoucí schopnost vyhledávat informace, důležité však je, že je zdůrazňováno tzv. podnětné čtenářské prostředí.

Většina předškolních dětí před vstupem do základní školy projevovala nejenom zájem o písmena, ale taktéž některá z nich již uměla rozlišovat (94,1 \%). Mezi problematické oblasti v předškolním vzdělávání, kterým by předškolní pedagogové měli věnovat více pozornosti, patří: 
- rozvoj receptivních jazykových dovedností, konkrétně vnímání a porozumění vyslechnutého textu;

- rozvoj jazykových dovedností produktivních, konkrétně správná výslovnost, celkový mluvený projev, souvislé vyjadřování ve větách.

ČŠI zveřejnila tematickou zprávu Podpora rozvoje čtenářské gramotnosti v předškolním a základním vzdělávání (2012), kde prezentovala, jaká je informovanost o čtenářské gramotnosti v mateřských školách, jaká opatření $\mathrm{k}$ podpoře a rozvoji předčtenářských dovedností byla přijata a jak se jim daří naplňovat cíle ve školních vzdělávacích programech v souladu s RVP PV (2004). Zde byl uplatňován kurikulární pohled na pregramostnost. Ze získaných dat vyplynulo, že ve sledovaných mateřských školách je hodnocení předčtenářských dovedností dětí prováděno nejčastěji poslechem a pozorováním (96\% oslovených MŠ), hodnocením osobního portfolia dítěte (75\% MŠ), popř́padě jiným způsobem (40 \% MŠ).

Ve školním roce 2009/2010 ČŠI sledovala, jak mateřské školy dosahují cílů rozvoje dovedností předcházejících čtení u dětí v MŠ (Porování..., 2013). $\mathrm{Z}$ výsledků šetření bylo zjištěno, že předškolní pedagogové v průběhu vzdělávacího procesu vesměs využívají účinné postupy, které umožňují dětem před samotnou četbou vybavovat, tř́́dit a porovnávat dosavadní zkušenosti s obsahem textu. Předškolní pedagogové používají účinně metody, které podporují aktivitu dětí nejenom v průběhu čtení, ale i činnosti směřující $\mathrm{k}$ reflexi obsahu předčítaného. Děti jsou vedeny $\mathrm{k}$ tomu, aby na základě předčteného textu uplatnily vlastní tvořivost $\mathrm{v}$ rámci výtvarných a pracovních činností. Většině dětí nečinila problémy sluchová či zraková percepce, dokázaly převyprávět slyšený příběh, pohádku a rozlišily grafické znaky či symboly. Problematičtější oblastí se jevila schopnost dětí zaujmout k předčítanému textu vlastní postoj a př́padně vyvodit „poučení pro život“. V závěru ČŠI doporučuje věnovat více pozornosti rozvoji schopnosti dětí domýšlet, jak by děj mohl pokračovat, a na základě otázek pedagoga rozvíjet schopnost zhodnotit předčítaný text.

Z výsledků analýzy ČŠI ze souboru 1995 hospitací v navštívených MŠ vyplynulo, že mezi nejvýznamnější faktory podpory čtenářské pregramotnosti z hlediska kurikula patří kvalifikovanost předškolních pedagogů, možnost specializovaného vzdělávání, účast školy a zapojení předškolních pedagogů do rozvojových projektů a jejich schopnost propojit vzdělávací činnosti s reálným prostředím, účast v programech dalšího vzdělávání pedagogických 
pracovníků. Rizika představuje velikost třídy a nižší informační gramotnost předškolních pedagogů s dlouhou pedagogickou praxí. Zde je vhodné zmínit specifičnost skupiny předškolních pedagogů: silná feminizace, převažují učitelky ve věku 36-55 let s absolvovaným středoškolským vzděláním zakončeným maturitní zkouškou (podrobněji ÚIV, 2011).

\subsection{Možnosti rozvoje čtenářské pregramotnosti v mateřských školách}

Další výsledky zajímavého šetření prezentovala Zajitzová (2011), která na vzorku 100 dětí v období před vstupem do 1. třídy základní školy sledovala úroveň jejich kompetencí v oblasti jazyka a řeči, což můžeme přiřadit k dispozičnímu pojetí pregramotnosti. Na základě získaných dat z výzkumného šetření vyplynulo, že nejvyšší úrovně tyto děti dosáhly v oblasti zrakové percepce, naopak nízké úrovně dosáhly v oblasti sluchové percepce a v oblasti formální vyspělosti řeči. Bylo zjištěno, že $89 \%$ dětí před zahájením povinné školní docházky dokáže poznat napsané své jméno a taktéž ho dokáže napsat, $12 \%$ dětí z výzkumného vzorku dokázalo již číst. Pro vývoj řeči je důležitý nejenom samotný rozvoj sluchové percepce, ale např. také vliv sociokulturního prostředí (srov. Zajitzová, 2011; Bytešníková, 2007). K dalším dovednostem, které souvisí nejenom s rozvojem řeči, ale i s předčtenářskou gramotností, patří prohlížení dětských knih, „čtení knih s dětmi. Dílčími výzkumy bylo zjištěno, že v rodinách dětí předškolního věku se objevuje tendence nahrazování osobního předčítání sledováním televize, poslechem CD atd. (srov. Zajitzová, 2011; Šmelová, 2004).

V letech 2011-2013 byl na Pedagogické fakultě Univerzity Karlovy realizován výzkum předčtenářských dovedností 648 dětí předškolního věku (5-6,5 let věku, 372 dívek, 276 chlapců) napříc Českou republikou (srov. Wildová \& Kropáčková, 2014). Cílem výzkumu bylo zjistit, ve kterých oblastech předčtenářských dovedností jsou děti lépe/hůře pro výuku čtení ve škole připraveni, zda se objevují rozdíly mezi jednotlivými skupinami (např. děvčaty a chlapci, dětmi z velkých a malých měst/vesnic, dětmi navštěvujícími předškolní zařízení a dětmi přicházejícími z domácí péče). Z předběžných výsledků (celkové zpracování bude teprve dokončeno) uvádíme dílčí závěry:

- Celkově jsou pro školní výuku čtení lépe připravena děvčata (nejlépe v oblasti řeči, sluchového vnímání a v oblasti pravolevé orientace).

- Chlapci projevili lepší výkony pouze v oblasti zrakového vnímání. 
- Při analýze výsledků činností zaměřených na zjištění úrovně pozornosti, představivosti a paměti nebyly zaznamenány podstatné rozdíly mezi chlapci a děvčaty.

- Z hlediska věku se jako předčtenářsky nejvyspělejší jevila skupina dětí 6-6,5letých.

- Nepotvrdily se významné rozdíly v připravenosti pro školní výuku čtení mezi dětmi z velkých vs. malých měst. Dá se předpokládat, že tento faktor není podstatným, v obou regionálních oblastech se děti rozvíjejí ve sledovaných oblastech obdobně.

- Jako významný faktor se objevil faktor sourozence; děti, které mají staršího sourozence, se ve většině šetření projevily jako lépe připraveny. Tento závěr koresponduje i s výsledky celostátního výzkumu počáteční čtenářské gramotnosti, ve kterém bylo mj. zjištěno, že starší sourozenec je velmi významným faktorem ovlivňujícím čtení.

- Významným faktorem byla i docházka do předškolního zařízení.

Dále je možné sledovat počiny v oblasti vlivů na rozvoj gramotnosti či pregramotnosti. Možnostem podpory čtenářské gramotnosti v rodinné edukaci se výzkumně věnovala Šauerová, která empiricky ověřila, že rodiče mohou velmi významně rozvíjet čtenářskou pregramotnost formou společných návštěv v knihovně, vedením deníčku společných aktivit, společnou komunikací, utvářením vztahu ke knize od nejútlejšího věku dítěte a zapojením rodičů společně s dětmi do některých projektů (srov. Šauerová, 2012).

K podobnému zajímavému zjištění došla Národní knihovna ČR, která realizovala v roce 2013 první celostátní reprezentativní průzkum 1519 dětí školního věku se zaměřením na četbu a na vztah dětí ke knihám a knihovnám. Na základě získaných informací dospěla Národní knihovna k názoru, že důležitým momentem pro rozvoj dětského čtenářství je předčítání rodičů v době, kdy ještě dítě neumí samo číst. Bohužel $12 \%$ dětských respondentů uvedlo, že jim rodiče nikdy nepředčítali (NÚV, 2013).

\subsection{Předpoklady pro rozvoj gramotnosti ve výzkumu}

Čtenářská gramotnost je předmětem zájmu vědeckých výzkumů, které sledují specifika nejenom v rozdílnosti jejího pojetí, ale i zákonitosti a rozdíly v jejím utváření, vlivy, které na ni působí, a metody a možnosti jejího rozví- 
jení. Velmi diskutovanou oblastí v zahraničí je, které předpoklady pro rozvoj gramotnosti jsou důležitější, existují totiž dva modely, které se mohou zdát opoziční - je to model percepčně-motorických předpokladů pro rozvoj gramotnostních dovedností a model jazykových předpokladů, ve kterém hraje hlavní úlohu oblast fonologie (srov. Kucharská, 2014).

V českém prostředí dále přetrvává zdůrazňování významů prvního modelu, tj. zrakových funkcí (zraková diferenciace, syntéza, zraková pamět', oční pohyby), laterality a motorických dovedností (hrubá i jemná motorika, grafomotorika). $V$ oblasti jazykových předpokladů se hovoří o výslovnosti, slovní zásobě, schopnosti formulovat. Zmiňuje se i úloha sluchového vnímání, zejména schopnost sluchové analýzy a syntézy. Fonologické schopnosti jsou však více diferencovány, zahrnují v sobě daleko více konkrétních dovedností, které si děti $\mathrm{v}$ předškolním věku osvojují spontánně, na základě rozvoje řeči a jazykových dovedností, ale také díky systematické podpoře $\mathrm{v}$ rámci předškolního vzdělávání či rodinné výchově.

Proto bylo významným počinem, že monotematické dvojčíslo časopisu Pedagogika (2012), prezentující v jednotlivých příspěvcích období pregramotnosti a počáteční gramotnosti jak v teoretické rovině (Wildová, 2012; Petrová, 2012), tak v rámci výzkumných šetření, přineslo několik studií zaměřených právě na fonologický model předpokladů pro čtení.

Seidlová Málková (2012) upozornila na výsledky studií, ve kterých bylo sledováno slabičné povědomí v předškolním věku. Jedná se o schopnost slabičného členění slova, kterou si dítě osvojovalo v rámci zácviku do testu. Pracuje se s žetony, symbolizujícími slabiky. Dalšími úlohami bylo rozpoznávání a skládání slabik. Výsledky ukázaly na rychlý vývoj fonologických dovedností mezi 4. a 6. rokem věku dítěte, což by se mohlo také promítnout do konstrukce diagnostických nástrojů pro odhalení dětí s oslabeným vývojem fonologických schopností. Je třeba připomenout, že všechny úkoly byly zadávány hravým způsobem a vyhovovaly principům kognitivního uchopení zadání $\mathrm{z}$ hlediska věku.

Další dvě studie (Jagerčíková \& Kucharská, 2012; Franke \& Mikulajová, 2012) sledovaly vztah mezi výkony $\mathrm{v}$ předškolním věku v testech, které mohou být prediktory úspěšného čtení a psaní po zahájení školní docházky, a to jak u dětí běžného vývoje, tak u dětí s rizikem obtíží ve čtení a psaní (rodinné riziko specifických poruch učení, vývojová dysfázie). Podobně jako v jiných jazycích byla zkoumána prediktabilita úloh zaměřených na fonologické 
uvědomování, rychlé automatické jmenování a rozpoznávání písmen, a to i ve vztahu k aktualizovaným obtížím ve čtení a psaní po nástupu do školy. Děti obou skupin jsou jimi skutečně ohroženy, což potvrzuje apel na včasné řešení vývojových obtíží předškolních dětí.

\section{Možnosti podpory rozvoje čtenářské pregramotnosti z hlediska učitelů aneb Čtenářská pregramotnost v přípravě učitelů}

V České republice je výchova a vzdělávání dětí předškolního věku, stejně jako ve většině evropských zemí, orientována na tzv. osobnostně orientovaný model, kdy se hlavní důraz klade na porozumění vývojovým a individuálním potřebám každého dítěte. Podstatou tohoto modelu je skutečnost, že každé dítě je individualitou, která je odlišná, a to jak v nadání, tak ve schopnostech, motivaci, ale i ve vzdělávacích možnostech. Těžiště osobnostně a humanisticky orientovaného předškolního vzdělávání je tedy v rozvoji osobnosti dítěte (podrobněji viz Helus, 2009; Opravilová \& Gebhartová, 2003; RVP PV, 2004).

Podstatnými rysy předškolního vzdělávání je princip individualizace, diferenciace, rozvoje vnitřní motivace atd. Významnými prostředky rozvoje jednotlivých oblastí je hra, spolupráce, vzájemná komunikace a motivace. Při rozvoji pregramotnosti je podstatná úzká a smysluplná spolupráce s rodiči (zákonnými zástupci) dítěte. Oni jsou těmi prvními, kteří počátky pregramotnosti u dětí kladou. Po narození na dítě hovoří, učí ho první slova, ukazují mu předměty, obrázky, čtou mu z prvních knih, učí ho básničky, sledují s ním pohádky, vyprávějí si s ním při různých situacích atd. Jejich role v rozvoji pregramotnosti je naprosto nezastupitelná a předškolní vzdělávání by tento potenciál mělo umět maximálně využít (společné návštěvy knihovny, společné předčítání knih v MŠ, společné řešení „čtenářských“ úkolů, společné projekty pro rodiče a děti - např. výroba první knihy atd.).

V počátečních stádiích rozvoje čtenářské gramotnosti žáků ve škole se jako velmi významný faktor ukazuje osobnost učitele (srov. Wildová \& Křivánek, 2009) a analogicky na rozvoj čtenářské pregramotnosti mají veliký vliv rodiče a předškolní pedagogové. Předškolní vzdělávání má doplňovat rodinnou výchovu a dítěti usnadňovat jeho další životní i vzdělávací cestu. Význam podpory a rozvoje čtenářské pregramotnosti můžeme poeticky charakterizovat ,jako vstupenku do světa poznání a kompas v labyrintu informací“. 
$\mathrm{Z}$ tohoto důvodu je nutné již v rámci pregraduální př́pravy předškolního pedagoga zařazení didaktiky rozvoje čtenářské pregramotnosti. Na PedF UK v Praze je v rámci pregraduálního bakalářského studia Učitelství pro mateřské školy zařazen speciálně předmět na podporu čtenářské pregramotnosti (tučně zvýrazněn) a další předměty, které s rozvojem čtenářské pregramotnosti úzce souvisejí (tabulka 1).

Tabulka 1

Předměty zaměřené na podporu čtenářské pregramotnosti na PedF UKv Praze

\begin{tabular}{lcc}
\hline Název předmětu & Rozsah & Zařazení v semestru \\
\hline Kultura mluveného projevu & $1 / 1$ & 1 \\
Literatura pro děti I & $1 / 1$ & 2 \\
Literatura pro děti II & $1 / 1$ & 3 \\
Dramatická výchova I & $1 / 1$ & 3 \\
Literární seminář s didaktikou & $0 / 2$ & 4 \\
Dramatická výchova II & $0 / 2$ & 4 \\
Rozvíjení čtenářské pregramotnosti & $1 / 1$ & 5 \\
Didaktika literární výchovy & $1 / 1$ & 5 \\
\hline
\end{tabular}

\section{Závěr}

Oblast rozvoje pregramotnosti u dítěte předškolního věku je oblastí z pohledu vzdělávání a budoucího sociálního začlenění nesmírně významnou. $\mathrm{V}$ předškolním období se kladou základy nejen čtenářské, ale i řady dalších pregramotností. Autorky provedly zhodnocení různých aspektů tohoto fenoménu a svou přehledovou studii ukončují několika závěry.

(1) Je možné konstatovat, že nejednotnost v užívání pojmů v oblasti pregramotnosti může souviset $s$ neujasněnými přístupy, která složka gramotnosti je hodnocena, zda je to oblast dispoziční (zde se autorkám jeví vhodným termínem např předpoklady pro rozvoj gramotnosti, pregramotnostní dovednosti nebo předčtenářské dovednosti), nebo zda se jedná o kurikulární aspekt gramotnosti. Autorky se ztotožňují s pojmem čtenářská pregramotnost a doporučují jeho užívání spíše než předčtenářská gramotnost. $V$ rámci rešerší výzkumů na toto téma je zřejmé, že by učitelky mateřských škol přivítaly zpřesnění pojmů $\mathrm{s}$ dopadem na RVP PV a vydání kvalitní metodiky v této oblasti. 
(2) Z hlediska významu předškolního období pro budoucí rozvoj gramotnosti byl nalezen spíše komplexní než izolovaný pohled, což hodnotíme pozitivně. Zdůrazňovány, a to i v rámci kurikulárních dokumentů, jsou všechny podstatné oblasti vývoje, které mohou do pregramotnosti a budoucí gramotnosti vstupovat, tj. osobnost dítěte, jeho motivace pro vlastní poznávání, rozvoj kognitivních i dílčích funkcí a v rámci tohoto ovlivňování má neopominutelnou úlohu rodina a mateřská škola. Předškolní instituce ( $v$ ČR především mateřská škola) nabízí dítěti přirozený a bezpečný prostor pro jeho rozvoj a může mu pomoci vyrovnat určité nedostatky rodinného prostředí. Podpora a rozvoj čtenářské pregramotnosti je závislá na konkrétních podmínkách předškolního vzdělávání (menší počet dětí ve třídě, skupinový a individuální přístup $\mathrm{k}$ dětem, prožitkové učení, hra a kvalitní pregraduální i celoživotní vzdělávání předškolních pedagogů atd.), podnětnosti rodinného prostředí a silné motivaci osobním př́kladem rodičů i pedagogů.

(3) Z provedených analýz výzkumů v oblasti pregramotnosti je patrné, že existují snahy o uchopení různých aspektů, které do rozvoje dítěte v předškolním věku vstupují, sledována je úloha kognitivních dílčích funkcí, které budou mít vztah k rozvoji čtení a psaní (bázová gramotnost), ale také osobnostně-motivační charakteristiky dítěte, které se budou spíše podílet na zájmu o čtení a rozvoji čtenářství. Obraz „kvalit“ předškolního dítěte $\mathrm{v}$ současné společnosti, které jsme měly možnost poznat prostřednictvím výzkumných studií, vypovídá, že v mnohých ohledech je "předškolák“ vybaven schopnostmi a dovednostmi, které v minulosti bývaly spojovány výhradně se školou (např. dovednost psaní svého jména, dovednost rozpoznávání hlásek, fonologické manipulace se slovy aj.). Kromě těchto dispozičních vlivů jsou zkoumány rozdíly z hlediska genderu a regionálních vlivů, v sociálních vlivech se ukazuje úloha staršího sourozence jako zprostředkovatele a pozitivní úloha mateřské školy.

(4) Na základě analýzy RVP PV, závěrů výročních zpráv ČŠI a prezentovaných výzkumů vyplynulo, že učitelky mateřských škol zařazují do předškolního vzdělávání aktivity podporující rozvoj čtenářské pregramotnosti, ale mají potíže se zařazováním aktivizujících metod, které podporují vyvozování informací z předčteného textu, domýšlení textu a aktivně stimulují děti k samostatnému vyhledávání informací, nebot’ s ohledem 
na věkovou a vzdělanostní strukturu se většina $\mathrm{z}$ nich s problematikou rozvoje a podpory čtenářské pregramotnosti nesetkala $v$ rámci pregraduálního studia, ale mnohdy ani v rámci dalšího vzdělávání učitelů.

Závěrem lze konstatovat, že právě přirozené sociální prostředí vrstevníků činí mateřskou školu v současné době nenahraditelnou, nebot' dítě je zde rozvíjeno, podporováno a motivováno s ohledem na jeho individuální potřeby i schopnosti, což mu usnadňuje jeho další životní dráhu a vytváří optimální předpoklady pro jeho další vzdělávací cestu. Mateřská škola v rámci úzké spolupráce s rodiči může nepřímo podporovat čtenářství rodičủ a $v$ rodinách obecně (např. tím, že si děti přinášejí do mateřské školy dětské knihy, kteréjim rodiče doma čtou, o těchto knihách pak vyprávějí a sdílejí své čtenářské prožitky s ostatními). Je výzkumně prokázáno, že čtenářství rodičů ovlivňuje čtenářství dětí, jelikož z dětí rodičů, kteří sami čtou, se častěji stávají silní čtenáři a také pravidelní návštěvníci knihoven. Nelze podceňovat předškolní výchovu dětí v rodině, avšak z hlediska komplexu předčtenářského rozvoje se jeví jako neúplná, někdy i nekoncepční. Z uvedeného lze tedy zobecnit, že bez podpory rodinného prostředí a samozřejmě bez kvalitního předškolního vzdělávání a kvalitních předškolních pedagogů se rozvoj čtenářské pregramotnosti, ale i počáteční čtenářské gramotnosti, může jen obtížně optimálně rozvíjet.

\section{Poděkování}

Autorky děkují členům redakce za odborné konzultace a anonymním recenzentům za cenné prípomínky.

\section{Literatura}

Bytešníková, I. (2007). Rozvoj komunikativních kompetencí u dětí předškolního věku. Brno: PdF MU.

Čtenářská gramotnost ve výuce. (2011). Praha: NÚV.

Doležalová, J. (2009). Produkty a efekty edukace. Gramotnost. In J. Průcha (Ed.), Pedagogická encyklopedie (s. 223-229). Praha: Portál.

EURYDICE. (2012). Key data on education in Europe 2012. Brussels: Eurydice.

Franke, H., \& Mikulajová, M. (2012). Předgramotnostní dovednosti slovensky hovořících dětí s různými profily jazykových schopností. Počáteční gramotnost. Pedagogika, 61(1-2), 164-177.

Gavora, P., \& Zápotočná, O., et al. (2003). Gramotnost' vývin a možnosti jej didaktického usmerňovanie. Bratislava: Univerzita Komenského.

Hart, L., \& Hartlová, H. (2000). Psychologický slovník. Praha: Portál.

Helus, Z. (2009). Dítě v osobnostním pojetí. Praha: Portál. 
Helus, Z. (2012). Reflexe nad problémy gramotnosti. Počáteční gramotnost. Pedagogika, $61(1-2), 205-210$.

Homolová, K. (2012). Rozvíjení čtenářské pregramotnosti a tvorba čtenářské prekompetence u předškolních dětí. In R. Wildová (Ed.), Čtenářská gramotnost a podpora jejího rozvoje ve škole (s. 17-36). Praha: PedF UK.

Jagerčíková, Z., \& Kucharská, A. (2012). Počátky gramotnosti u česky mluvících dětí s vývojovou dysfázií ve srovnání s běžně se vyvíjejícími vrstevníky. Počáteční gramotnost. Pedagogika, 61(1-2), 150-163.

Kádnerová, B. (1982). Metodika literární výchovy v mateřské škole. Praha: SPN.

Konkretizované očekávané výstupy. (2012). Dostupné z http://www.msmt.cz/vzdelavani/ predskolni-vzdelavani/konkretizovane-ocekavane-vystupy-rvp-pv

Kropáčková, J. (2013). (Ne)zodpovězené otázky v koncepci předškolního vzdělávání. Příspěvek prezentovaný na dvacáté výroční konferenci České pedagogické společnosti v Liberci.

Kucharská, A. (2014, v tisku). Riziko dyslexie - pregramotnostní dovednosti a rozvoj gramotnosti $v$ rizikových skupinách. Praha: PedF UK.

Kucharská, A., \& Veverková, J. (2012). Vývoj písařských dovedností v průběhu první třídy u analyticko-syntetické metody a genetické metody. Počáteční gramotnost. Pedagogika, 61(1-2), 81-96.

Mertin, V. (2003). Podpora a rozvoj čtenářských dovedností v předškolním věku. In M. Mertin \& I. Gillernová (Eds.), Psychologie pro učitelky mateřských škol (s. 121-129). Praha: Portál.

Najvarová, V. (2010). Čtenářské strategie žáků prvního stupně základní školy. Pedagogická orientace, 20(3), 49-65.

NÚV. (2013). Stále méně dětí baví čtení. Dostupné z http://www.nuv.cz/publikace/stale-menedeti-bavi-cteni?highlightWords=gramotnost

OECD. (2012). Quality matters in early childhood education and care. Paris: OECD. Dostupné z: http://www.oecd-ilibrary.org/education/quality-matters-in-early-childhood-educationand-care-czech-republic-2012_9789264176515-en;jsessionid=2rfp29qdk04d1.x-oecdlive-02

OECD. (2013). Education at a glance: OECD indicators. Paris: OECD.

Opravilová, E., \& Gebhartová, V. (2003). Rok v mateřské škole. Kurikulum předškolní výchovy. Praha: Portál.

Petrová, Z. Vygotského koncepty a tézy a počiatočnom rozvíjaní jazykovej gramotnosti. Pedagogika, 61(1-2), 22-33.

Podpora rozvoje čtenářské gramotnosti v předškolním a základním vzdělávání. Tematická zpráva. (2011). Praha: ČS̆I.

Porovnání zjištění z let 2009/2010 a 2012/2013 doplněné o šetření finanční gramotnosti v roce 2012/2013. (2013). Praha: ČŠI.

Průběžný souhrn diskuze k úpravám RVP PV k 20. lednu 2013. (2013). Dostupné z http://static. ow.ly/docs/RVPPV_souhrn_130120_126A.pdf

Průcha, J., Walterová, E., \& Mareš, J. (2003). Pedagogický slovník. Praha: Portál.

Pupala, B \& Zápotočná, O. (2001). Vzdělávanie jako formovanie kultúrnej gramotnosti. In Z. Kolláriková \& B. Pupala (Eds.), Předškolní a primární pedagogika. Predškolská a elementárna pedagogika. (s. 261-269). Praha: Portál.

Rabušicová, M. (2002). Gramotnost: staré téma v novém pohledu. Brno: Georgetown.

Program výchovné práce v jeslích a mateřských školách. (1984). Praha: SPN.

Rámcový vzdělávací program pro předškolní vzdělávání. (2004). Praha: VÚP. 
Seidlová Málková, G. (2012). Vývoj a diagnostika slabičného povědomí v předškolním věku. Počáteční gramotnost (Monotematické číslo). Pedagogika, 61(1-2), 97-110.

Straková, J., et al., (2002). Vědomosti a dovednosti pro život: čtenářská, matematická a prírodovědná gramotnost patnáctiletých žáků v zemích OECD. Praha: ÚIV.

Strnadová, K., Bičǐštová, E., \& Veberová, E. (1989). Literární výchova v mateřské škole. Praha: VÚP.

Šauerová, M. (2012). Vliv vývoje sociálních interakcí dětí předškolního a mladšího školního věku na možnost podpory čtenářské gramotnosti v rodinné edukaci. Počáteční gramotnost (Monotematické ćíslo). Pedagogika, 61(1-2), 126-136.

Šmelová, E. (2004). Kniha v rodině předškoláka. Informatorium 11(3), 8-9.

Švancarová, D., \& Kucharská A. (2012). Test rizika poruch čtení a psaní pro rané školáky. Praha: Dyscentrum.

Syslová, Z., Borkovcová, I., \& Průcha, J. (2014). Péče a vzdělávání dětí v raném věku. Komparace české a zahraniční studie. Praha: Wolters Kluwer.

ÚIV. (2011). Školství pod lupou 2010. Praha: ÚIV.

UNESCO. (1958). Recommendation concerning the international standardization of educational statistics. Paris: OECD.

Vykoukalová, V., \& Wildová, R. (2013). Čtenářská gramotnost žáků 1. stupně a možnosti jejího rozvoje. Praha: PedF UK v Praze.

Výroční zpráva České školní inspekce za školní rok 2012/2013. (2013). Praha: ČSI.

Wildová, R. (2012). Rozvoj pregramotnosti a počáteční čtenářské gramotnosti v kurikulu evropských zemí. Pedagogika, 61(1-2), 10-21.

Wildová, R., \& Kropáčková, J. (2014). Early childhood pre-reading literacy development. 6th World Conference on Educational Sciences Proceedings (v tisku).

Wildová, R., \& Křivánek, Z. (2009). Produkty a efekty edukace. Základy gramotnosti (počáteční čtenářská gramotnost). In J. Průcha (Ed.), Pedagogická encyklopedie (s. 230-234). Praha: Portál.

Zajitzová, E. (2011). Předškolní vzdělávání a jeho význam pro rozvoj jazyka a řeči. Praha: Hnutí R.

Zpravodaj PISA in Focus 40. (2014). Dostupné z http://www.oecd.org/pisa/pisaproducts/ pisainfocus/pisa-in-focus-n40-(eng)-final.pdf

\section{Autorky}

PhDr. Jana Kropáčková, Ph.D., Univerzita Karlova v Praze, Pedagogická fakulta,

Katedra primární pedagogiky, Magdalény Rettigové 4, 11639 Praha 1,

e-mail: jana.kropackova@pedf.cuni.cz

Doc. PaedDr. Radka Wildová, CSc., Univerzita Karlova v Praze, Pedagogická fakulta,

Katedra primární pedagogiky, Magdalény Rettigové 4, 11639 Praha 1,

e-mail: radka.wildova@pedf.cuni.cz

PhDr. PaedDr. Anna Kucharská, Ph.D., Univerzita Karlova v Praze, Pedagogická fakulta, Katedra psychologie, Magdalény Rettigové 4, 11639 Praha 1, e-mail: anna.kucharska@pedf.cuni.cz 


\title{
The approaches to and the development of pre-reading literacy in pre-school age
}

\begin{abstract}
The focus of this paper is on pre-reading literacy, which is considered to be an important part of lifelong learning. The foundations of reading literacy, other literacies, character features, and motivation for learning are set mainly in the pre-primary age. The aim of this study is to describe the approach to pre-reading literacy in Czech education, analyse the terminology changes and summarize the research outcomes focused on the concept of pre-reading literacy, and its support and development in home environment. In the first part, the authors focus on the terminology changes, its use in Czech pre-school education, and specify the terminology from the point of view of literacy development and in the context of the current Czech pre-school curriculum. The second part presents outcomes of Czech pre-reading literacy research. The third part discusses the possibilities to include the above mentioned topics into the curriculum of pre-school teachers at Faculty of Education at Charles University in Prague. It also mentions other ways to make the pre-school development more effective as it is considered to be one of the key periods in the development of reading literacy. Further on, the authors explain the preference for the term pre-reading literacy. They also highlight why it is necessary to approach pre-reading literacy in a complex way, not only in research, but also in teacher training and in pre-school education in general.
\end{abstract}

Keywords: pre-school education, pre-school, pre-school age child, family education, reading competence, reading literacy, pre-reading education, pre-reading literacy

Průcha, J. (2014). Andragogický výzkum. Praha: Grada.

Andragogický výzkum není v České republice intenzivně rozvíjen. Publikace je zaměřena na jeho podporu tím, že nejprve vysvětluje, co vytváří výzkumné pole andragogiky, co jsou andragogické edukační procesy a další témata týkající se vzdělávání dospělých (např. vzdělávací potřeby profesních skupin, volba vzdělávací dráhy, styly a strategie učení dospělých aj.). Podrobněji jsou objasňovány analýzy efektivnosti vzdělávání dospělých. $\mathrm{V}$ druhé části knihy jsou vysvětleny metody a přístupy vhodné pro andragogický výzkum. Publikace je zakončena přehledem infrastruktury andragogického výzkumu, především v zahraničí. Kniha je určena pro studenty a pracovníky učitelských oborů na vysokých školách a pro začínající výzkumníky v pedagogice a andragogice. 